\title{
Disentangling the Climate-conflict Nexus: Empirical and Theoretical Assessment of Vulnerabilities and Pathways
}

\author{
Jürgen Scheffran ${ }^{1}$, Michael Brzoska ${ }^{2}$, Jasmin Kominek ${ }^{1,3}$, P. Michael Link ${ }^{1,4} \&$ Janpeter Schilling ${ }^{1,5}$ \\ ${ }^{1}$ Research Group Climate Change and Security, Institute of Geography and KlimaCampus, University of \\ Hamburg, Hamburg, Germany \\ ${ }^{2}$ Institute for Peace Research and Security Policy and KlimaCampus, University of Hamburg, Hamburg, \\ Germany \\ ${ }^{3}$ Institute of Sociology, University of Hamburg, Hamburg, Germany \\ ${ }^{4}$ Research Unit Sustainability and Global Change, Center for Earth System Research and Sustainability, \\ University of Hamburg, Hamburg, Germany \\ ${ }^{5}$ Department of Geography, Colgate University, Hamilton, NY, USA \\ Correspondence: Jürgen Scheffran, Research Group Climate Change and Security, Institute of Geography and \\ KlimaCampus, University of Hamburg, Grindelberg 7 \#2015, D-20144 Hamburg, Germany. Tel: \\ 49-40-42838-7722. E-mail: juergen.scheffran@zmaw.de
}

\author{
Received: July 30, 2012 Accepted: September 8, 2012 Online Published: September 28, 2012 \\ doi:10.5539/res.v4n5p1 URL: http://dx.doi.org/10.5539/res.v4n5p1
}

Research for this study was funded in part by the German Science Foundation (DFG) through the Cluster of Excellence "CliSAP" (EXC177).

\begin{abstract}
Recent research has provided new insights into the relationship between climate change and violent conflict. In this review we compare the results, methodologies, and data applied in the peer-reviewed literature to recap the current state of the debate. While long-term historical studies suggest a coincidence between climate variability and armed conflict, empirical findings are less conclusive for recent periods. Disentangling the climate-conflict nexus, we discuss causal pathways such as precipitation changes, freshwater scarcity, food insecurity, weather extremes, and environmental migration. A geographic differentiation indicates that countries with low human development are particularly vulnerable to the double exposure of natural disasters and armed conflict. Thus, effective institutional frameworks and governance mechanisms are important to prevent climate-induced conflicts and to strengthen cooperation. Applying an integrative framework connecting climate change, natural resources, human security, and societal stability, we pinpoint future research needs.
\end{abstract}

Keywords: climate change, human security, integrative framework, societal stability, violent conflict, vulnerability

\section{Introduction}

While recent research has provided new insights into the relationship between climate change and violent conflict (Gleditsch, 2012, Scheffran et al., 2012a) there is no consensus yet in the literature about its nature and extent. Those who claim a strong causal connection are facing serious doubts by scholars who find no or only weak empirical evidence for such claims. In this literature review we summarize the current state of the debate by addressing the following research questions: Do peer-reviewed studies find significant linkages between climate change and violent conflict? Which factors are found to be of particular importance? What methodologies and data are used in the studies? What conclusions can be drawn from the analysis of the studies? What future paths of research on the linkages between climate change and violent conflict appear to be particularly promising?

While long-term historical studies suggest a coincidence between climate variability and armed conflict, empirical findings are less conclusive for recent periods. Understanding the different views provides a foundation for the prediction of future impacts on violent conflict. However, it is argued here that more 
comprehensive approaches are needed to disentangle the complex climate-conflict nexus. We briefly discuss the key intervening variables and causal pathways between precipitation changes, freshwater scarcity, and food insecurity as well as weather extremes and environmental migration. Pathways may differ in their relevance for distinguishable types of violence and regional contexts. Theoretical insights suggest that low-level violence is more likely to be linked to the effects of climate change than full scale wars. Empirical findings indicate that climate-conflict linkages vary significantly between the world's regions. For illustration, we provide a broad-brush geographic differentiation by countries to show that countries with low human development are particularly vulnerable to the double exposure of natural disasters and armed conflict.

This highlights the point that climate change is not the only important parameter of future violence. Other factors such as human development, effective institutions, and governance also affect the likelihood of violent conflict. Economic, political, and social factors on local, regional and global levels are interlinked with broader effects of climate change. As a promising basis for future research, we suggest an integrative framework of the pathways between climate change and violent conflict that can be applied to model and empirically calibrate linkages between climate change, natural resources, human security, and societal stability.

This review summarizes key lessons from the scientific literature, identifies research needs, and draws conclusions for future research and policy. After introducing our methodology, we systematically assess the current state of empirical research on the link between climate change and violent conflict. Going beyond the mere use of global data sets we consider selected intermediate pathways and address regional differences in how climate change and violent conflict affect human security. In this context, the role of human development and institutional processes in multiplying or minimizing potential conflicts is discussed. Finally, we identify shortcomings, challenges and questions for future research within the integrative framework of human-environment interaction.

\section{Methods}

Because of the complexity of the research matter, this article utilizes two research methods. The primary focus is on a comparative review of the scientific literature on the linkages between climate-related indicators and data on violent conflict using large-n designs. To come to conclusions about the effect of climate change on violent conflict with validity beyond single cases, we limit the analysis to (quantitative) empirical studies using regression analysis based on conflict and climate data because of their increasing importance in the recent debate and the difficulties associated with the comparison of (qualitative) field-research studies. We analyze the results of recent relevant studies, classifying them with the help of a number of criteria such as specified climate-conflict link, conflict type, region, analyzed period (Table 1) and data used to carve out differences and similarities. We limit the analysis to studies published since 2004 and accept their academic credibility as articles published in peer-reviewed scientific journals.

As we show, there is no consensus in the quantitative literature regarding the effect of climate change on violent conflict. Since the assumption of a direct link is disputable, we proceed to a second methodological approach, the development and illustrative description of a model of greater complexity, distinguishing various pathways of interaction between climate change, the environment, and human society. This second method comprises an analysis of state-based vulnerability, climate, conflict, development, economic, and natural disaster data. We identify both the various climate-related phenomena as well as the geographic regions that may be of particular importance for the future study of the links between climate change and violent conflict.

We illustrate the importance of the proposed model of the intermediate factors and indirect pathways between climate change and conflict with some readily available data and relevant literature including recently published studies of our own. To show the geographical distribution of vulnerabilities we relate an established indicator of climate change vulnerability and the most widely used global dataset on conflicts (Figure 2, see following section). We also plot data of battle-deaths against the deaths of (potentially) climate change related natural disasters and the level of human development (Figure 3), which to our knowledge is done for the first time in a peer-reviewed publication. To show how temperature, per capita gross domestic product, the number of violent conflicts, the number of democratic countries as well as battle and disasters deaths have evolved over time, we combine the respective data in a comparative overview (Figure 4) .

\section{Empirical Findings}

Until now, research on the climate-conflict nexus has largely relied on quantitative methodologies based on statistical analyses of climate and conflict data and on qualitative assessments of causal mechanisms in case studies. In contrast to the extensive modeling in climate science, models of climate-conflict linkages are rare (example in Devitt \& Tol, 2012; see review in Scheffran et al., 2012b). Using different concepts of climate 
change and conflict, most studies in this field are based on a selected set of climatic or weather-related variables (temperature, precipitation, and extreme weather events) that are correlated with specific aspects of violent conflict (particularly the onset or number of armed conflicts).

Quantitative empirical research that analyzes various regions and time periods reaches differing conclusions about the influence of climate variables on armed conflict (Table 1). Studies that use quantitative data over long historical periods generally tend to find a correlation between climate variability and armed conflict. One study that shows such a link for pre-industrial Europe concludes that cooler periods in pre-industrial Europe are more likely related to periods of violence than warmer phases (Tol \& Wagner, 2010). The authors support their conclusion by referring to a regression analysis that confirms the positive correlation between cooler periods and the higher war frequency and intensity. Similar results have been found for the Northern Hemisphere (Zhang et al., 2011) and Eastern China (Zhang et al., 2007 and Table 1).

As shown in Table 1, studies for more recent periods come to differing and sometimes opposing results. In an important study, Miguel and others (2004) have found that an increase of armed conflicts was correlated with economic shocks, for which rainfall variation has been used as an instrumental variable in agriculturally-dependent regions in Africa that can be influenced by climate change. However, the specification of rainfall measures has been criticized because of its counterintuitive formalism (Ciccone, 2011). In another major study, a significant linkage between civil war and temperature has been found for the period 1981 to 2002 in Africa (Burke et al., 2009). This study in turn has been challenged on the basis that the results were not robust to alternative model specifications and the application of more recent data (Buhaug, 2010). In what is probably the strongest but also most puzzling statement of a statistical correlation between weather-related data and armed conflict, Hsiang and others (2011) find a strong effect of the El Niño Southern Oscillation (ENSO) on armed conflict for the period 1950-2004. The "probability of new civil conflicts arising throughout the tropics doubles during El Niño years relative to La Niña years" (Hsiang et al., 2011:438). Yet, key questions remain on the connection between climate change and the El Niño phenomenon (Gergis \& Fowler, 2009), even more on the link to conflict. Is El Niño an adequate indicator for the impact of climate change on violent conflict? Is it possible that El Niño redirects civil conflict away from La Niña years without raising the overall number of conflict incidences? What are the main pathways of the effects of El Niño years on civil conflict? For low-income countries the study leaves open "if (1) they respond strongly because they are low-income, (2) they are low income because they are sensitive to ENSO, or (3) they are sensitive to ENSO and low income for some third unobservable reason" (Hsiang et al., 2011:440) .

Table 1. Results of key peer reviewed quantitative studies since 2004 on the link between climate change and violent conflict

\begin{tabular}{llllll}
\hline link & $\begin{array}{l}\text { specified } \\
\text { link }\end{array}$ & $\begin{array}{l}\text { conflict } \\
\text { type }\end{array}$ & region & period analyzed & reference \\
\hline $\mathrm{Y}$ & $+\mathrm{T}|-\mathrm{P}|+\mathrm{D}$ & $\mathrm{s}$ & global & $1950-2004$ & Hsiang et al., 2011 \\
& $\rightarrow+\mathrm{C}$ & & & & \\
$\mathrm{Y}$ & $-\mathrm{L} \rightarrow+\mathrm{C}$ & $\mathrm{s}$ & global & $1980-92$ & Theisen, 2008 \\
$\mathrm{Y}$ & $-\mathrm{L} \rightarrow+\mathrm{C}$ & $\mathrm{s}, \mathrm{ns}$ & global & $1990-2004$ & Raleigh and Urdal, 2007 \\
$\mathrm{Y}$ & $+\mathrm{D} \rightarrow+\mathrm{C}$ & $\mathrm{s}$ & global & $1950-2000$ & Nel and Righarts, 2008 \\
$\mathrm{Y}$ & $+\mathrm{D} \rightarrow-\mathrm{C}$ & $\mathrm{s}$ & global & $1950-2008$ & Slettebak, 2012 \\
$\mathrm{Y}$ & $\Delta \mathrm{P} \rightarrow+\mathrm{C}$ & $\mathrm{s}$ & Africa & $1981-1999$ & Miguel et al., 2004 \\
$\mathrm{Y}$ & $+\mathrm{P} \rightarrow+\mathrm{C}$ & $\mathrm{s}$ & Africa & $1990-2008$ & Hendrix and Salehyan, 2012 \\
$\mathrm{Y}$ & $+\mathrm{P} \rightarrow+\mathrm{C}$ & $\mathrm{ns}$ & East Africa & $1950-1994 / 1971-2010$ & Adano et al., 2012 \\
$\mathrm{Y}$ & $+\mathrm{P} \rightarrow+\mathrm{C}$ & $\mathrm{ns}$ & East Africa & $1989-2004$ & Theisen, 2012 \\
$\mathrm{Y}$ & $\Delta \mathrm{P} \rightarrow+\mathrm{C}$ & $\mathrm{s}, \mathrm{ns}$ & East Africa & $1997-2009$ & Raleigh and Kniveton, 2012 \\
$\mathrm{Y}$ & $+\mathrm{V} \rightarrow+\mathrm{C}$ & $\mathrm{s}$ & East Africa & $2000-2006$ & Rowhani et al., 2011 \\
$\mathrm{Y}$ & $+\mathrm{T} \rightarrow+\mathrm{C}$ & $\mathrm{s}$ & SSA & $1981-2002$ & Burke et al., 2009 \\
$\mathrm{Y}$ & $-\mathrm{P} \rightarrow+\mathrm{C}$ & $\mathrm{s}, \mathrm{ns}$ & East Asia & $220 \mathrm{BC}-1839 \mathrm{AD}$ & Bai and Kung, 2011
\end{tabular}




\begin{tabular}{|c|c|c|c|c|c|}
\hline $\mathrm{Y}$ & $-\mathrm{T} \rightarrow+\mathrm{C}$ & $\mathrm{s}$ & East Asia & AD10-1900 & Zhang et al., 2010 \\
\hline $\mathrm{Y}$ & $-\mathrm{T} \rightarrow+\mathrm{C}$ & $\mathrm{s}$ & East Asia & 800BC-AD1911 & Zhang et al., 2007 \\
\hline $\mathrm{Y}$ & $-\mathrm{T} \rightarrow+\mathrm{C}$ & $\mathrm{s}$ & Europe & $1500-1800$ & Zhang et al., 2011 \\
\hline $\mathrm{N}$ & $+\mathrm{T} \otimes \mathrm{C}$ & $\mathrm{s}$ & global & $1816-2000$ & Gartzke, 2012 \\
\hline $\mathrm{N}$ & $\Delta \mathrm{T} \mid \Delta \mathrm{P} \otimes \mathrm{C}$ & $\mathrm{s}$ & global & $1980-2004$ & Koubi et al., 2012 \\
\hline $\mathrm{N}$ & $+\mathrm{D} \otimes \mathrm{C}$ & s & global & $1980-2007$ & Bergholt and Lujala, 2012 \\
\hline $\mathrm{N}$ & $\Delta \mathrm{P} \otimes \mathrm{C}$ & $\mathrm{s}$ & Africa & $1960-2004$ & Buhaug and Theisen, 2012 \\
\hline $\mathrm{N}$ & $+\mathrm{T} \mid \Delta \mathrm{P} \otimes \mathrm{C}$ & $\mathrm{s}$ & SSA & $1981-2002$ & Buhaug, 2010 \\
\hline $\mathrm{N}$ & -W区C & $\mathrm{s}, \mathrm{ns}$ & Sahel & $1960-2006$ & Benjaminsen et al., 2012 \\
\hline \multirow[t]{2}{*}{ A } & $\mathrm{W} \rightarrow+\mathrm{C}$ & $\mathrm{s}$ & global & $1880-2001$ & Gleditsch et al., 2006 \\
\hline & W凶C & & & & \\
\hline \multirow[t]{2}{*}{$\mathrm{A}$} & $-\mathrm{W} \rightarrow+\mathrm{C}$ & $\mathrm{s}$ & global & $1981-2000$ & Gizelis and Wooden, 2010 \\
\hline & $+\mathrm{W} \rightarrow+\mathrm{C}$ & & & & \\
\hline \multirow[t]{2}{*}{ A } & $-\mathrm{L} \rightarrow-\mathrm{C}$ & $\mathrm{s}$ & global & $1950-2000$ & Urdal, 2005 \\
\hline & $-\mathrm{L} \rightarrow+\mathrm{C}$ & & & & \\
\hline \multirow[t]{2}{*}{ A } & $\Delta \mathrm{P} \rightarrow+\mathrm{C}$ & $\mathrm{s}$ & SSA & $1981-2002$ & Hendrix and Glaser, 2007 \\
\hline & -L |-W凶C & & & & \\
\hline A & $-\mathrm{T} \sim+\mathrm{C}$ & $\mathrm{s}, \mathrm{ns}$ & Central Europe & $1500-1900$ & Tol and Wagner, 2010 \\
\hline
\end{tabular}

The column "link" denotes whether there is a significant link between the variables (y) or not (n) or whether the link is ambivalent (a). $\mathrm{P}=$ precipitation, $\mathrm{T}=$ temperature, $\mathrm{D}=$ disaster, $\mathrm{W}=$ freshwater, $\mathrm{L}=$ land, $\mathrm{V}=$ vegetation, $\mathrm{C}=$ conflict,$\rightarrow=$ leads to, $+=$ increase, $-=$ decrease, $\Delta=$ change (increase or decrease), $\bigotimes=$ no link, $\sim=$ weak link. Example: $+\mathrm{P} \rightarrow+\mathrm{C}=$ increase in precipitation leads to an increase in conflict, $\mid=$ and/or, $\mathrm{s}=$ state involved, ns $=$ no state involved, SSA $=$ Sub-Sahara Africa, ${ }^{*}$ projection.

Based on the mixed evidence, earlier reviews conclude that there is "only limited support for viewing climate change as an important influence on armed conflict" (Gleditsch, 2012:3), but that "environmental changes may, under specific circumstances, increase the risk of violent conflict" (Bernauer et al., 2012:1). We find it important to understand these conditions to move beyond the limitations in current approaches towards more systematic assessments.

As shown in Table 1, quantitative empirical studies are suited to identify significant correlations between climate variables and violent conflict, but they have limited explanatory power with respect to characterizing the causal pathways and their dynamics. In other words, empirical studies may find a correlation but they are hardly able to explain why. Furthermore, quantitative studies predominantly rely on state-based data captured in the UCDP/PRIO Armed Conflict Dataset (Table 1). However, PRIO's definition of conflict limits the studies to conflicts with governmental involvement and an intensity of at least 25 battle deaths per year (PRIO, 2011a). Hence low-level events such as protests, riots and inter-group violence are disregarded in such datasets. As climatic changes are expected to mostly affect local (non-government) conflicts, this is in general a significant shortcoming of quantitative studies. Recent projects like the Armed Conflict Location and Events Dataset (ACLED), the Social, Political and Economic Event Database (SPEED) and the Social Conflict in Africa Database (SCAD) attempt to fill the gap by including non-state conflicts, low-level violence, social instability events, and geo-referenced spatio-temporal patterns (see Busby et al., 2012; Nardulli \& Leetaru, 2012; Raleigh \& Kniveton, 2012; and the supplement in Scheffran et al., 2012a). Due to the huge amount of data it will take time until the upcoming databases cover longer periods and major parts of the world.

In contrast to correlation-orientated quantitative studies, qualitative studies are able to disentangle the complex conflict factors, but they have difficulties to support their claims beyond case-specific data and to establish causality. Both approaches may not be robust against variation of model variables and assumptions, for instance regarding conflict type, involved parties, regional samples, and time periods. They extend past data into a future world with unprecedented rates of temperature rise and its associated consequences. They also lack experience in human and societal responses to such changes. Conflict and cooperation, which are of core interest for the 
relationship between climate change and violence, may cancel each other out at the global scale.

\section{Intermediate Factors and Indirect Pathways}

We suggest that a reason for the different findings in the empirical literature on the effects of climate change and violent conflict is the theoretical basis used for quantitative work, which does not sufficiently consider the complexities of the issue. As suggested earlier (Scheffran et al., 2012a; Scheffran et al., 2012b), a complex model of the direct and indirect causal relationships between climate change and conflict is needed. Figure 1 shows connections between the climate system, natural resources, human security, and societal stability. Climate change in itself has various dimensions, with multiple relevant effects on the environment, economics, society, and politics. Most important in this context is the frequency and intensity of extreme weather events, the variability of weather parameters such as temperature and precipitation, and long-term changes in such parameters. These variables may have direct impacts on social systems or indirect implications through other pathways affecting natural resources and human security, which together can lead to ambiguous results.

For each pathway, the consequences of climate change depend on how vulnerable affected natural and social systems are and how sensitive they respond to the stress. At each level, human intervention can influence the systems, e.g. through mitigation and adaptation strategies to reduce risks, strengthen resilience, and improve sustainability. The main focus here is the impact of climate change on conflict, which generally refers to social or political incompatibilities over interests, values, or methods. The definitions of conflict vary with respect to the number of actors, casualties, and the degree of violence. In the context of climate change most studies refer to armed conflict, in which actors use force to achieve their aims.

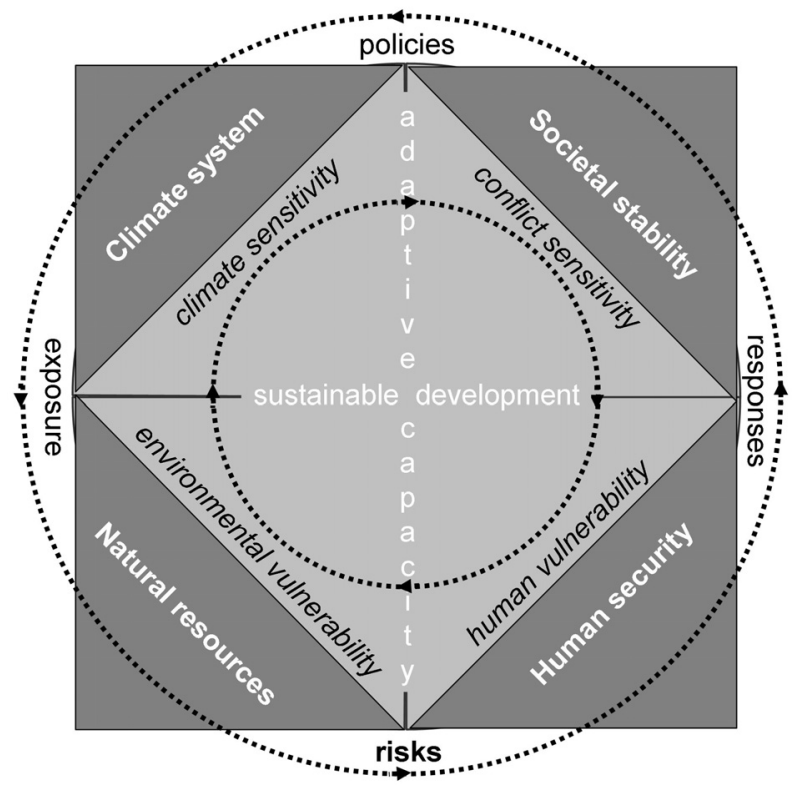

Figure 1. Analytical framework of linkages between the climate system, natural resources, human security, and societal stability (based on Scheffran et al., 2012b)

There is a wealth of literature on each of the intermediate phenomena. Therefore, we focus only on key messages and references in the subsequent aggregation. Since the 1990s, there has been an extensive scientific debate on how the scarcity of natural resources such as minerals, water, energy, fish, and land affects violence and armed conflict (Homer-Dixon, 1994; Bächler, 1999). While many case studies suggest that environmental degradation and resource scarcity undermine human well-being, the effect on violent conflict "appears to be contingent on a set of intervening economic and political factors that determine adaptation capacity" (Bernauer et al., 2012:1). Particular attention has been placed on the following intermediate factors (WBGU, 2008; Scheffran and Battaglini, 2011).

\subsection{Precipitation Changes and Variability}

While lack of precipitation and drought may increase resource conflicts in some cases (Opiyo et al., 2012), other 
assessments support the proposition that the occurrence of conflict, caused by issues on rainfed agriculture or pastoralism, is more likely in rainy than in dry seasons (Table 1). For instance, some studies find that in Kenya the conflict likelihood, in the form of livestock raiding, is greater in years with rainfall abundance than in drought years (Theisen, 2012). People "reconcile their differences and cooperate" (Adano et al., 2012:77) in dry seasons of relative scarcity. Others argue that strong deviations from average precipitation in both directions are related to the onset of violent conflict (Hendrix \& Salehyan, 2012; Raleigh \& Kniveton, 2012). Generally, political and economic marginalization of ethnic groups is a more significant factor influencing violence than drought (Eriksen \& Lind, 2009; Theisen, 2012). Other studies (e.g. Koubi et al., 2012) do not directly test for a relationship between climate variability and conflict but rather proceed in two stages: they first estimate the effect of temperature on economic growth and then assess the relationship between growth and conflict.

\subsection{Freshwater Resources and Scarcity}

Systematic empirical assessments demonstrate that international river systems are more associated with low-level conflicts and diplomatic tensions than with full-scale wars (e.g. Brochmann \& Hensel, 2009, Bernauer $\&$ Siegfried, 2012). According to the Transboundary Freshwater Dispute Database the evidence for war between countries over water is low. The number of international water agreements has been rising over the past decades, which indicates growing cooperation (Wolf, 2007; De Stefano et al., 2012).

\subsection{Land and Food}

Climate change is likely to contribute to food insecurity in parts of the world (Gahukar, 2009), while food insecurity can contribute to violence (Messer, 2009). This has been highlighted by the "food riots" that occurred in several countries between 2007 and 2011, which correlated with rising food prices (Bush, 2010; Sternberg, 2012). So far, there is little explicit evidence of climate change as a contributing factor in this context (Johnstone \& Mazo, 2011). Also, the role of climate change in conflicts among pastoral and farming communities over land and pasture in Sub-Sahara Africa is ambivalent (Adano et al., 2012; Benjaminsen et al.; 2012). One study indicates that rainfall-related economic shocks increase land invasions and hence the potential for conflict, as shown for regions with highly unequal land distribution in Brazil (Hidalgo et al., 2010).

\subsection{Weather Extremes}

In addition to the study on the ENSO phenomenon (Hsiang et al., 2011), additional publications have found relevant evidence of links between extreme weather events and armed conflict. This includes studies of natural disasters (Nel \& Righarts, 2008), which arguably have similar effects as those predicted by extreme weather events such as floods and storms. However, other assessments (Slettebak, 2012) do not support this result and find no increased likelihood of civil armed conflict after natural disasters. Among those, Slettebak (2012) argues that in crisis situations cooperation prevails over conflict. Future studies using broader sets of data including low-level violence should take into account both conflict and cooperation as consequences of weather-related extreme events.

\subsection{Environmental Migration}

There is a wide range of estimates on the number of future migrants who are driven by environmental and climatic changes (Jakobeit \& Methmann, 2012). Empirical findings reach no consensus whether environmental migration can act as a precursor for violence (Barnett \& Adger, 2007; Reuveny, 2007). Recent studies rather suggest to treat migration as an important adaptation measure to climate change (Black et al., 2011), which could strengthen the resilience of affected communities, e.g. through remittances (Scheffran et al., 2012c).

\section{Geographical Distribution of Vulnerabilities}

A large body of literature suggests that the impact of climate change on human beings and societies is shaped by the vulnerabilities specific to each region (e.g. IPCC, 2007; Füssel, 2011; Samson et al., 2011). The vulnerability to climate impacts can be broken down into three factors: i) exposure to climate change, ii) sensitivity to climate change, and iii) adaptive capacity (IPCC, 2007). While exposure can be considered to be independent from conflict, the other two cannot, suggesting that the climate-conflict link is not a one-way road. In Figure 2 we identify countries that have recently been sensitive to violent conflict (using the number of armed conflicts in the past three decades) and countries that are vulnerable to future climate change (using an established indicator for climate vulnerability). This provides a geographical representation of countries that are facing the double exposure to both climate change and violent conflict, only one of these phenomena, or none of them. Several questions arise: Will regions that are prone to violent conflict also become more affected by climate change? Could increased climate impacts undermine adaptive capacity and add to conflict? How do climate vulnerability and violent conflict interact in "hot spots" that suffer from this double exposure? 


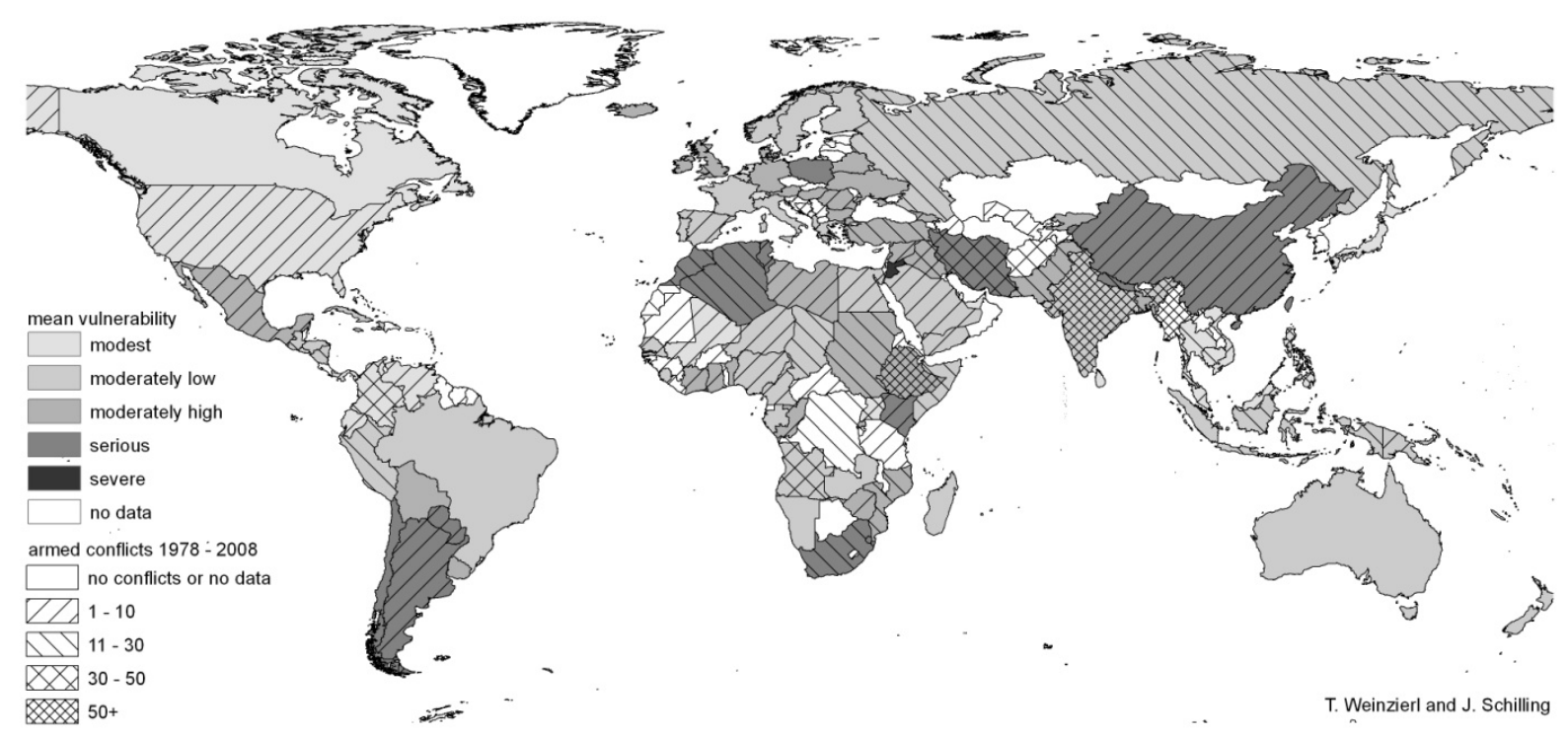

Figure 2. Mean vulnerability to future climate change and the number of recent armed conflicts. The vulnerability shown is the mean between the vulnerability index for climate sensitivities of $1.5^{\circ} \mathrm{C}$ and $5.5^{\circ} \mathrm{C}$, both calculated for the IPCC A2 emission scenario until 2050 (Yohe et al., 2006b). The vulnerability index is a measure of climate change exposure, sensitivity, and adaptive capacity (for details see Yohe et al., 2006a, 2006b).

The conflict data are from UCDP/PRIO Armed Conflict Dataset v.4-2011 (PRIO, 2011b)

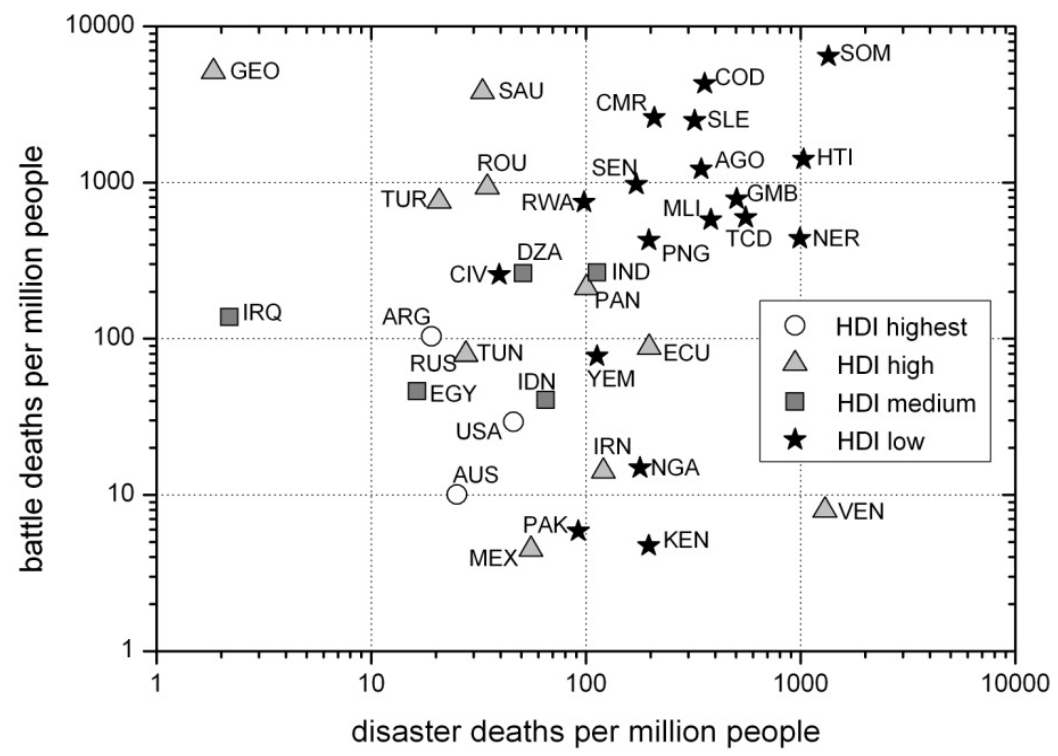

Figure 3. Battle deaths vs. disaster deaths in countries that have experienced casualties in both categories between 1978 and 2008 (UCDP/PRIO and EM-DAT for the time period 1978-2008). The disasters considered are drought, epidemic, extreme temperature, flood, insect infestation, wet mass movement, storm, and wildfire.

The categorization of development is based on the 2011 Human Development Index

Country codes: AGO Angola, ARG Argentina, AUS Australia, CIV Cote d'Ivoire, CMR Cameroon, COD Congo, DZA Algeria, ECU Ecuador, EGY Egypt, GEO Georgia, GMB Gambia, HTI Haiti, IDN Indonesia, IND India, IRN Iran, IRQ Iraq, KEN Kenya, MEX Mexico, MLI Mali, NER Niger, NGA Nigeria, PAK Pakistan,

PAN Panama, PNG Papua New Guinea, ROU Romania, RUS Russia, RWA Rwanda, SAU Saudi Arabia,

SEN Senegal, SLE Sierra Leone, SOM Somalia, TCD Chad, TUN Tunisia, TUR Turkey,

USA United States of America, VEN Venezuela, YEM Yemen 
Although definite answers cannot be given yet, it is worthwhile to examine the factors that shape this interaction. A comparison of the number of deaths from natural disasters and battle-related deaths in the past (scaled for comparability using the population in each country) reveals that both are highest in countries with a low human development index (see Figure 3). Many of these countries are home to the world's poorest people who already experience increased threats to their lives and health that undermine human development. If climate change adds to these risks and vulnerabilities, it can increase humanitarian crises and aggravate existing conflicts without directly causing them.

\section{Governmental Responses, Governance, and Institutional Frameworks}

Human development and adaptive capacity are fundamental ingredients to contain the double exposure of conflict and climate risks. Their interaction is related to the concept of human security, which refers to the reduction and elimination of vital anthropogenic threats to the life and health of individuals and communities (Commission on Human Security, 2003). The potential effects of climate change on human security are decisively influenced by the responses of local, national, and international actors, which may both reduce or increase the likelihood of climate-induced violence.

While global temperature has been rising in the past decades, the number of armed conflicts has declined since the end of the Cold War (Figure 4). The growing wealth per capita and the spread of democracies increase the chance of an expansion of adaptive capacity in many parts of the world, which counters climate exposure and sensitivity. Until the global financial crisis of 2008, humanitarian aid and development assistance have increased (OECD, 2012). In many parts of the world this contributed to important improvements in the living conditions of people who are potentially most vulnerable to the effects of climate change. With the global financial crisis, however, the situation has become more severe again.

International efforts to prevent and manage conflicts have been strengthened, which has considerably reduced the number of armed conflicts and battle deaths (Figure 4). In recent years, however, this trend seems to have come to a standstill, and it is not clear how conflict prevention and management will evolve in the future. A particular problem is the capacity of conflict management institutions from local to global levels to deal with sub-national conflicts and multiple crises simultaneously. Effective institutional frameworks, governance mechanisms, and democratization are often seen as an important precondition for peaceful management of conflict. Democracies have rarely fought each other in the past, and democratic states also have seen fewer incidences of civil war in the past decades (Gleditsch et al., 2009). The number of democratic states has generally grown in waves over the past half century, which concurred with a decline in armed conflict. More recently, low-level violence and the number of fragile states with weak institutions have slowly increased (Stewart \& Brown, 2010; Marshall \& Cole, 2011). Still, there is a risk that institutions could be overwhelmed by climate change related crises (WBGU, 2008).

While the United States and the United Kingdom consider climate change as a major future problem for national and global security, other states such as Russia and China have paid minor attention to this issue so far. The divergent views have been expressed in the two controversial debates in the UN Security Council in 2007 (initiated by the UK) and in 2011 (initiated by Germany). Main areas of military concern are interventions in fragile states, the securing of borders, and access to resources, e.g. in the Mediterranean or in the Arctic region (see Brzoska, 2012; Brauch, 2010). The debate on the securitization of climate change has enhanced the focus on its risks but this discourse also entails the danger of the militarization of climate change with unintended consequences. For instance, it may instigate policy makers to choose violent means when facing crisis situations with links to climate change, which raises the likelihood of armed conflict. Furthermore, it may undermine the conditions for cooperation and reduce the financial means available for mitigation and adaptation measures. Some of these responses to climate change could become causes of conflict themselves (Webersik, 2010) such as the competition of bioenergy and food production for land, or the potential quarrel between states over climate engineering. Some of the technical fixes to reduce climate change or its effects could be introduced in unilateral action by some states at the expense of other states. In general, it is important to consider the implications of mitigation and adaptation measures for the interests of the many groups of stakeholders involved and to aim at avoiding the creation or further aggravation of conflicts. 

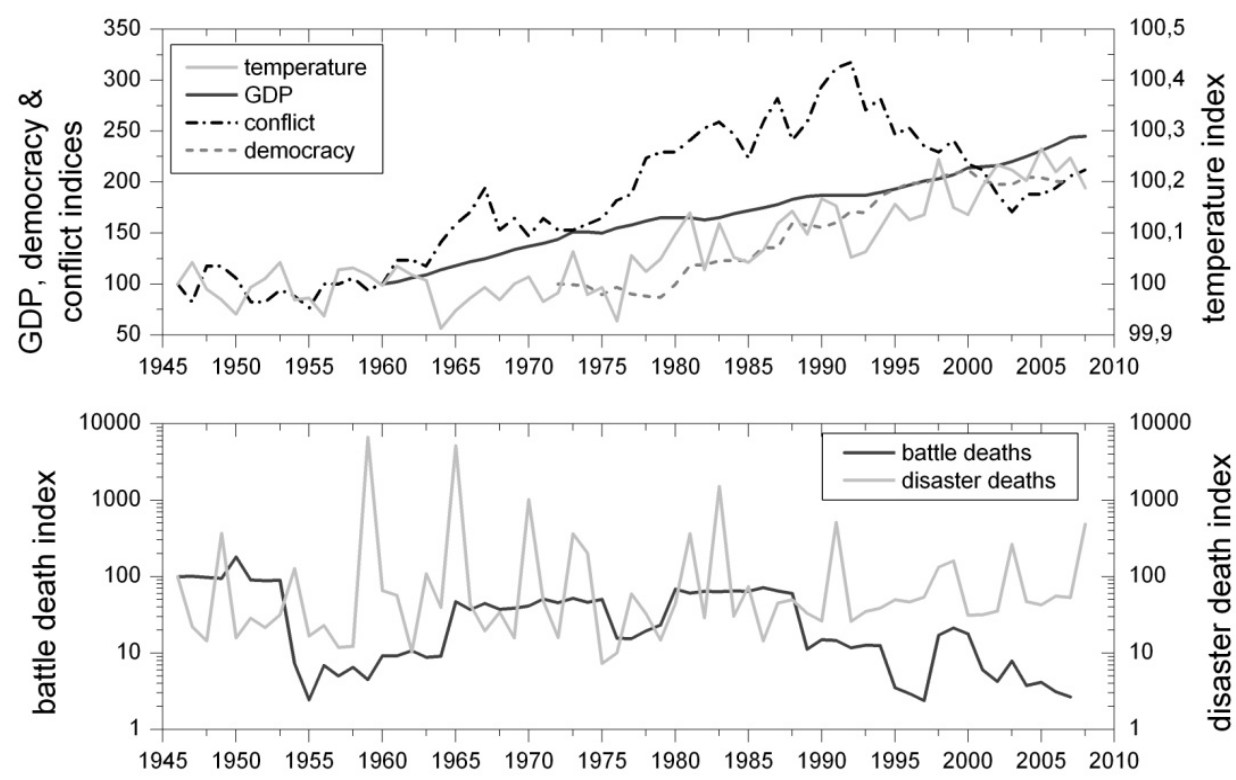

Figure 4. Development of indices of global sea surface temperature (top right scale, based on Kelvin), per capita gross domestic product, number of violent conflicts, democratic countries (top left scale), and casualties from battle and disasters (bottom logarithmic scales) (NOAA, World Bank Online Database, UDCP/PRIO, Freedom

House Index, Correlates of War Interstate Wars, EM-DAT). For all indices 100\% is set for a reference year

\section{Conclusions and Future Research Challenges}

A significant part of the current literature supports the argument that climate change has an influence on violent conflict in at least some regions of the world. However, while quantitative studies tend to provide evidence for a link between climate change and violent conflict over longer historical periods, results for recent periods are more ambiguous. Other trends and events may have had a larger influence on violent conflict than climate change. Two examples from the recent past are the end of the Cold War and the increase in international activity to stop armed conflict in many parts of the world. However, without strong mitigation efforts future climate change may by far exceed levels that have been reached in human history. If major 'tipping points' of societal stability are reached, climate change may become a major driver of armed conflict in the future.

At present, such predictions are based on presumptions and not on evidence. Assessments of the links between climate change and violent conflict are still unclear about many important elements. A relevant constraint is the lack of understanding of the escalation from non-violent to violent conflict. Further important limitations of current research are inadequate data (e.g. on rainfall), insufficient indicators (e.g. of drought or conflict independent of violence), and the lack of comparability and generalization for different regional contexts and intermediate pathways. More micro level data on violent conflict would help to understand feedback effects between climate change and conflict at subnational levels (Nardulli \& Leetaru, 2012). In addition, data on social and political processes that can lead to violence are needed. Causality is hard to measure as numerous variables, complex interactions, and long chains are involved.

Future analysis may more specifically look at the various pathways of interaction between the climate system, natural resources, human security, and societal stability that have been indicated in Figure 1. Besides the direct effects of climate change on society, e.g. through extreme weather events, the more indirect causal chains need further investigation. This includes large-scale impacts on ecosystems, food and water supply, health problems, income shocks, human migration, and ultimately violent conflict. It is key to improve the understanding of vulnerability and sensitivity of the affected systems with regard to a changing climate. It is important to determine whether these systems are able to maintain resilience, and how the factors and processes shape adaptive capacities, strategies, and their successful implementation. A related question is how these systems respond and interact if the climate stress exceeds critical thresholds of adaptive capacity. Will such development trigger tipping elements, cascading events, and ultimately violent conflict, or will it rather lead to coordinated responses and cooperation to jointly address the future global challenges, e.g. by a transformation towards low-carbon societies? 
As explained before, it is necessary to use a more complex, comprehensive approach to study the links between climate change and violent conflict. The various linkages indicated in Figure 1 open up a multitude of possibilities of how climate change may be linked, via intermediate factors, to violent conflict - or not, if the pathways do not materialize or are moderated by other factors shaping violent conflict. A lot of research has been done and is on the way to investigate those linkages. However, it needs to be better related and integrated into a framework such as the one suggested here. The prime objective of the framework is to combine quantitative empirical analyses, qualitative case studies, and modeling of the complex human-environment interactions. To further address the ambiguities, uncertainties, and limitations of current quantitative research, data are needed on low-level conflicts and their geographical and temporal distribution. Models could build on a rich set of modeling tools from complexity science, multi-agent systems, social network analysis, and conflict assessment that extend previous data and experiences into future scenarios, covering different social, economic, and political contexts. Developing an integrative framework would help to overcome the current deficits in research and identify under which conditions climate change would lead to violent conflict or its prevention.

\section{References}

Adano, W. R., Dietz, T., Witsenburg, K., \& Zaal, F. (2012). Climate change, violent conflict and local institutions in Kenya's drylands. Journal of Peace Research, 49, 65-80. http://dx.doi.org/10.1177/0022343311427344

Bächler, G. (1999). Environmental degradation in the south as a cause of armed conflict. In A. Carius, \& K. M. Lietzmann (Eds.), Environmental Change and Security: A European Perspective (pp. 107-130). Berlin: Springer.

Bai, Y., \& Kung, J. K. S. (2011). Climate Shocks and Sino-nomadic Conflict. Review of Economics and Statistics, 93, 970-981. http://dx.doi.org/10.1162/REST_a_00106

Barnett, J., \& Adger, W. N. (2007). Climate change, human security and violent conflict. Political Geography, 26, 639-655. http://dx.doi.org/10.1016/j.polgeo.2007.03.003

Benjaminsen, T. A., Alinon, K., Buhaug, H., \& Buseth, J. T. (2012). Does climate change drive land-use conflicts in the Sahel?. Journal of Peace Research, 49, 97-111. http://dx.doi.org/10.1177/0022343311427343

Bergholt, D., \& Lujala, P. (2012). Climate-related natural disasters, economic growth, and armed civil conflict. Journal of Peace Research, 49, 147-162. http://dx.doi.org/10.1177/0022343311426167

Bernauer, T., \& Siegfried, T. (2012). Climate change and international water conflict in Central Asia. Journal of Peace Research, 49, 227-239. http://dx.doi.org/10.1177/0022343311425843

Bernauer, T., Böhmelt, T., \& Koubi, V. (2012). Environmental changes and violent conflict. Environmental Research Letters, 7, online. http://dx.doi.org/10.1088/1748-9326/7/1/015601

Black, R., Adger, W. N., Arnell, N. W., Dercon, S., Geddes, A., \& Thomas, D. (2011). The effect of environmental change on human migration. Global Environmental Change, 21(Supplement 1), S3-S11. http://dx.doi.org/10.1016/j.gloenvcha.2011.10.001

Brauch, H. G. (2010). Climate Change and Mediterranean Security. Papers IEMed. March 2010, Barcelona: European Institute of the Mediterranean.

Brochmann, M., \& Hensel, P. R. (2009). Peaceful Management of International River Claims. International Negotiation, 14, 393-418. http://dx.doi.org/10.1163/157180609X432879

Brzoska, M. (2012). Climate Change as a Driver of Security Policy. In J. Scheffran, M. Brzoska, H. G. Brauch, P. M. Link, \& J. Schilling (Eds.), Climate Change, Human Security and Violent Conflict (pp. 165-184). Berlin: Springer. http://dx.doi.org/10.1007/978-3-642-28626-1_8

Buhaug, H., \& Theisen, O. M. (2012). On Environmental Change and Armed Conflict. In J. Scheffran, M. Brzoska, H. G. Brauch, P. M. Link, \& J. Schilling (Eds.), Climate Change, Human Security and Violent Conflict (pp. 43-55). Berlin: Springer. http://dx.doi.org/10.1007/978-3-642-28626-1_2

Buhaug, H. (2010). Climate not to blame for African civil wars. Proceedings of the National Academy of Sciences, 107, 16477-16482. http://dx.doi.org/10.1073/pnas.1005739107

Burke, M. B., Miguel, E., Satyanath, S., Dykema, J. A., \& Lobell, D. B. (2009). Warming increases the risk of civil war in Africa. Proceedings of the National Academy of Sciences, 106, 20670-20674. http://dx.doi.org/10.1073/pnas.0907998106

Busby, J. W., Smith, T. G., White, K. L., \& Strange, S. M. (2012). Locating Climate Insecurity: Where Are the Most Vulnerable Places in Africa?. In J. Scheffran, M. Brzoska, H. G. Brauch, P. M. Link, \& J. Schilling 
(Eds.), Climate Change, Human Security and Violent Conflict (pp. 463-512). Berlin: Springer. http://dx.doi.org/10.1007/978-3-642-28626-1_23

Bush, R. (2010). Food Riots: Poverty, Power and Protest. Journal of Agrarian Change, 10, 119-129. http://dx.doi.org/10.1111/j.1471-0366.2009.00253.x

Ciccone, A. (2011). Economic shocks and civil conflict: A comment. American Economic Review: Applied Economics, 3, 215-227. http://dx.doi.org/10.1257/app.3.4.215

Commission on Human Security. (2003). Human Security Now. New York: Commission on Human Security.

De Stefano, L., Duncan, J., Dinar, S., Stahl, K., Strzepek, K. M., \& Wolf, A. T. (2012). Climate change and the institutional resilience of international river basins. Journal of Peace Research, 49, 193-209. http://dx.doi.org/10.1177/0022343311427416

Devitt, C., \& Tol, R. S. (2012). Civil war, climate change, and development: A scenario study for sub-Saharan Africa. Journal of Peace Research, 49, 129-145. http://dx.doi.org/10.1177/0022343311427417

Eriksen, S., \& Lind, J. (2009). Adaptation as a Political Process: Adjusting to Drought and Conflict in Kenya's Drylands. Environmental Management, 43, 817-835. http://dx.doi.org/10.1007/s00267-008-9189-0

Füssel, H. M. (2011). How inequitable is the global distribution of responsibility, capability, and vulnerability to climate change: A comprehensive indicator-based assessment. Global Environmental Change, 20, 597-611. http://dx.doi.org/10.1016/j.gloenvcha.2010.07.009

Gahukar, R. T. (2009). Food security: The challenges of climate change and bioenergy. Current Science, 96, 26-28.

Gartzke, E. (2012). Could climate change precipitate peace?. Journal of Peace Research, 49, 177-192. http://dx.doi.org/10.1177/0022343311427342

Gergis, J., \& Fowler, A. (2009). A history of ENSO events since A.D. 1525: implications for future climate change. Climatic Change, 92, 343-387. http://dx.doi.org/10.1007/s10584-008-9476-z

Gizelis, T. I., \& Wooden, A. E. (2010). Water resources, institutions, \&amp; intrastate conflict. Political Geography, 29, 444-453. http://dx.doi.org/10.1016/j.polgeo.2010.10.005

Gleditsch, N. P. (2012). Whither the weather? Climate change and conflict. Journal of Peace Research, 49, 3-9. http://dx.doi.org/10.1177/0022343311431288

Gleditsch, N. P., Furlong, K., Hegre, H., Lacina, B., \& Owen, T. (2006). Conflicts over shared rivers: Resource scarcity or fuzzy boundaries? Political Geography, 25, 361-382. http://dx.doi.org/10.1016/j.polgeo.2006.02.004

Gleditsch, N. P., Hegre, H., \& Strand, H. (2009). Democracy and Civil War. In M. Midlarsky, \& A. Arbor (Eds.), Handbook of War Studies III (pp. 155-192). Michigan: University of Michigan Press.

Hendrix, C. S., \& Glaser, S. M. (2007). Trends and triggers: Climate, climate change and civil conflict in Sub-Saharan Africa. Political Geography, 26, 695-715. http://dx.doi.org/10.1016/j.polgeo.2007.06.006

Hendrix, C. S., \& Salehyan, I. (2012). Climate change, rainfall, and social conflict in Africa. Journal of Peace Research, 49, 35-50. http://dx.doi.org/10.1177/0022343311426165

Hidalgo, F. D., Naidu, S., Nichter, S., \& Richardson, N. (2010). Economic Determinants of Land Invasions. Review of Economics and Statistics, 92, 505-523. http://dx.doi.org/10.1162/REST_a_00007

Homer-Dixon, T. (1994). Environmental Scarcities and Violent Conflict - Evidence from Cases. International Security, 19, 5-40. http://dx.doi.org/10.2307/2539147

Hsiang, S. M., Meng, K. C., \& Cane, M. A. (2011). Civil conflicts are associated with the global climate. Nature, 476, 438-441. http://dx.doi.org/10.1038/nature10311

Intergovernmental Panel on Climate Change (IPCC). (2007). Climate Change 2007 - Climate Change Impacts, Adaptation and Vulnerability. Working Group II, Geneva: Cambridge University Press.

Jakobeit, C., \& Methmann, C. (2012). Climate Refugees' as Dawning Catastrophe? A Critique of the Dominant Quest for Numbers. In J. Scheffran, M. Brzoska, H. G. Brauch, P. M. Link, \& J. Schilling (Eds.), Climate Change, Human Security and Violent Conflict (pp. 301-314). Berlin: Springer. http://dx.doi.org/10.1007/978-3-642-28626-1_16

Johnstone, S., \& Mazo, J. (2011). Global Warming and the Arab Spring. Survival, 53, 11-17. 
http://dx.doi.org/10.1080/00396338.2011.571006

Koubi, V., Bernauer, T., Kalbhenn, A., \& Spilker, G. (2012). Climate variability, economic growth, and civil conflict. Journal of Peace Research, 49, 113-127. http://dx.doi.org/10.1177/0022343311427173

Marshall, M. G., \& Cole, B. R. (2011). Global Report 2011 - Conflict, Governance, and State Fragility. Vienna, VA: Center for Systemic Peace.

Messer, E. (2009). Rising Food Prices, Social Mobilizations, and Violence: Conceptual Issues in Understanding and Responding to the Connections Linking Hunger and Conflict. NAPA Bulletin, 32, 12-22. http://dx.doi.org/10.1111/j.1556-4797.2009.01025.x

Miguel, E., Satyanath, S., \& Sergenti, E. (2004). Economic Shocks and Civil Conflict: An Instrumental Variables Approach. Journal of Political Economy, 112, 725-753. http://dx.doi.org/10.1086/421174

Nardulli, P. F., \& Leetaru, K. H. (2012). Climate Change, Societal Stability, and the SID Project. In J. Scheffran, M. Brzoska, H. G. Brauch, P. M. Link, \& J. Schilling (Eds.), Climate Change, Human Security and Violent Conflict (pp. 57-76). Berlin: Springer. http://dx.doi.org/10.1007/978-3-642-28626-1_3

Nel, P., \& Righarts, M. (2008). Natural disasters and the risk of violent civil conflict. International Studies Quarterly, 52, 159-185. http://dx.doi.org/10.1111/j.1468-2478.2007.00495.x

Opiyo, F. E. O., Wasonga, O. V., Schilling, J., \& Mureithi, S. (2012). Resource-based Conflicts in Drought-prone Northwestern Kenya: The Drivers and Mitigation Mechanisms. African Journal of Environmental Science and Technology, accepted.

Organisation for Economic Co-operation and Development (OECD). (2012). Analyses of aid - how much aid is delivered, where and for what purpose. Retrieved July 27, 2012, from http://www.oecd.org/document/48/0,3746,en_2649_34447_42396656_1_1_1_1,00.html

Peace Research Institute Oslo (PRIO). (2011a). UCDP/PRIO Armed Conflict Dataset Codebook Version 4-2011. Retrieved July 27, 2012, from http://www.pcr.uu.se/digitalAssets/63/63324_Codebook_UCDP_PRIO_Armed_Conflict_Dataset_v4_2011. pdf

Peace Research Institute Oslo (PRIO). (2011b). UCDP/PRIO Armed Conflict Dataset Version 4-2011. Retrieved July 27, 2012 from http://www.pcr.uu.se/research/ucdp/datasets/ucdp_prio_armed_conflict_dataset

Raleigh, C., \& Kniveton, D. (2012). Come rain or shine: An analysis of conflict and climate variability in East Africa. Journal of Peace Research, 49, 51-64. http://dx.doi.org/10.1177/0022343311427754

Raleigh, C., \& Urdal, H. (2007). Climate change, environmental degradation and armed conflict. Political Geography, 26, 674-694. http://dx.doi.org/10.1016/j.polgeo.2007.06.005

Reuveny, R. (2007). Climate change-induced migration and violent conflict. Political Geography, 26, 656-673. http://dx.doi.org/10.1016/j.polgeo.2007.05.001

Rowhani, P., Degomme, O., Guha-Sapir, D., \& Lambin, E. (2011). Malnutrition and conflict in East Africa: the impacts of resource variability on human security. Climatic Change, 105, 207-222. http://dx.doi.org/10.1007/s10584-010-9884-8

Samson, J., Berteaux, D., Mcgill, B. J., \& Humphries, M. M. (2011). Geographic disparities and moral hazards in the predicted impacts of climate change on human populations. Global Ecology and Biogeography, 20, 532-544. http://dx.doi.org/10.1111/j.1466-8238.2010.00632.x

Scheffran, J., \& Battaglini, A. (2011). Climate and conflicts: the security risks of global warming. Regional Environmental Change, 11, S27-S39. http://dx.doi.org/10.1007/s10113-010-0175-8

Scheffran, J., Brzoska, M., Kominek, J., Link, M., \& Schilling, J. (2012a). Climate Change and Violent Conflict. Science, 336, 869-871. http://dx.doi.org/10.1126/science.1221339

Scheffran, J., Link, P. M., \& Schilling, J. (2012b). Theories and Models of the Climate-Security Interaction: Framework and Application to a Climate Hot Spot in North Africa. In J. Scheffran, M. Brzoska, H. G. Brauch, P. M. Link, \& J. Schilling (Eds.), Climate Change, Human Security and Violent Conflict (pp. 91-131). Berlin: Springer. http://dx.doi.org/10.1007/978-3-642-28626-1_5

Scheffran, J., Marmer, E., \& Sow, P. (2012c). Migration as a contribution to resilience and innovation in climate adaptation: Social networks and co-development in Northwest Africa. Applied Geography, 33, 119-127. http://dx.doi.org/10.1016/j.apgeog.2011.10.002 
Slettebak, R. T. (2012). Don't blame the weather! Climate-related natural disasters and civil conflict. Journal of Peace Research, 49, 163-176. http://dx.doi.org/10.1177/0022343311425693

Sternberg, T. (2012). Chinese drought, bread and the Arab Spring. Applied Geography, 34, 519-524. http://dx.doi.org/10.1016/j.apgeog.2012.02.004

Stewart, F., \& Brown, G. (2010). Fragile States - Overview, Centre for Research on Inequality, Human Security and Ethnicity. Retrieved July 27, 2012, from http://www.crise.ox.ac.uk/pubs/CRISE\%20Overview\%203.pdf

Theisen, O. M. (2008). Blood and Soil? Resource Scarcity and Internal Armed Conflict Revisited. Journal of Peace Research, 45, 801-818. http://dx.doi.org/10.1177/0022343308096157

Theisen, O. M. (2012). Climate clashes? Weather variability, land pressure, and organized violence in Kenya, 1989-2004. Journal of Peace Research, 49, 81-96. http://dx.doi.org/10.1177/0022343311425842

Tol, R., \& Wagner, S. (2010). Climate change and violent conflict in Europe over the last millennium. Climatic Change, 99, 65-79. http://dx.doi.org/10.1007/s10584-009-9659-2

Urdal, H. (2005). People vs. Malthus: Population Pressure, Environmental Degradation, and Armed Conflict Revisited. Journal of Peace Research, 42, 417-434. http://dx.doi.org/10.1177/0022343305054089

Webersik, C. (2010). Climate change and security: a gathering storm of global challenges. Santa Barbara: Praeger.

Wissenschaftlicher Beirat der Bundesregierung Globale Umweltveränderungen (WBGU). (2008) World in Transition - Climate Change as a Security Risk. German Advisory Council on Global Change, London: Earthscan.

Wolf, A. T. (2007). Shared Waters: Conflict and Cooperation. Annual Review of Environment and Resources, 32, 241-269. http://dx.doi.org/10.1146/annurev.energy.32.041006.101434

Yohe, G., Malone, E., Brenkert, A., Schlesinger, M., Meij, H., \& Xing, X. (2006a). Global Distributions of Vulnerability to Climate Change. Integrated Assessment, 6, 35-44.

Yohe, G., Malone, E., Brenkert, A., Schlesinger, M., Meij, H., Xing, X., \& Lee, D. (2006b). A Synthetic Assessment of the Global Distribution of Vulnerability to Climate Change from the IPCC Perspective that Reflects Exposure and Adaptive Capacity. New York: Clumbia University.

Zhang, D. D., Lee, H. F., Wang, C., Li, B., Pei, Q., Zhang, J., \& An, Y. (2011). The causality analysis of climate change and large-scale human crisis. Proceedings of the National Academy of Sciences, 108, 17296-17301. http://dx.doi.org/10.1073/pnas.1104268108

Zhang, D. D., Zhang, J., Lee, H. F., \& He, Y. Q. (2007). Climate Change and War Frequency in Eastern China over the Last Millennium. Human Ecology, 35, 403-414. http://dx.doi.org/10.1007/s10745-007-9115-8

Zhang, Z., Tian, H., Cazelles, B., Kausrud, K. L., Bräuning, A., Guo, F., \& Stenseth, N. C. (2010). Periodic climate cooling enhanced natural disasters and wars in China during AD 10-1900. Proceedings of the Royal Society B: Biological Sciences, 277, 3745-3753. http://dx.doi.org/10.1098/rspb.2010.0890 